Jafar Taheri

ORCID 0000-0002-5424-409X

Department of Architecture, Ferdowsi University of Mashhad

(Mashhad, Iran)

j.taheri@um.ac.ir

\title{
The impacts of architecture and decorative arts on health based on medical sources in the Muslim societies during the medieval era
}

\begin{abstract}
This article aims to provide a historical overview of the impact of architecture and decorative arts on health and health preservation in Muslim societies during the medieval era.

Based on primary medical sources, this article provides a historical interpretation of the theoretical origin of the ignored link between medicine and architecture (and decorative arts).

Our findings indicate that some empirical results concerning the effects and aspects of built environments (architectural spaces) on health and treatment-both physical and mental- have been considered in the medical sources.

Practical instructions of these sources introduced two theoretical achievements: 1) an introduction to the historical

\begin{tabular}{|c|c|c|c|c|}
\hline $\begin{array}{l}\text { PUBLICATION } \\
\text { INFO }\end{array}$ & $\begin{array}{c}\text { Ptudia } \\
\text { Cistoriae } \\
\text { cientiarum }\end{array}$ & $\begin{array}{r}\text { e-ISSN 2543-702X } \\
\text { ISSN 2451-3202 }\end{array}$ & 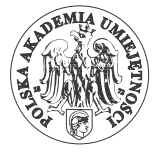 & $\begin{array}{c}2 \\
\text { DIAMOND } \\
\text { OPEN ACCESS }\end{array}$ \\
\hline \multicolumn{5}{|c|}{$\begin{array}{l}\text { CITATION } \\
\text { Taheri, Jafar 2021: The impacts of architecture and decorative arts on health based on medical sources } \\
\text { in the Muslim societies during the medieval era. Studia Historiae Scientiarum 20, pp. 861-891. } \\
\text { DOI: } \underline{10.4467 / 2543702 \text { XSHS.21.025.14056. }}\end{array}$} \\
\hline \multicolumn{2}{|c|}{$\begin{array}{l}\text { RECEIVED: } 10.12 .2020 \\
\text { ACCEPTED: } 19.06 .2021 \\
\text { PUBLISHED ONLINE: } 13.09 .2021\end{array}$} & $\begin{array}{l}\text { ARCHIVE } \\
\text { POLICY } \\
\text { Green SHERPA/ } \\
\text { RoMEO Colour }\end{array}$ & 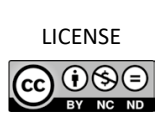 & $\begin{array}{l}\text { Crossref } \\
\text { Similarity Check } \\
\text { Powered by iThenticate }\end{array}$ \\
\hline
\end{tabular}
\end{abstract}


knowledge of environmental health and design of healthy places, and 2) a comparative analogy of the built environment and human nature (organism), which became a theoretical basis for the relationship between natural sciences, architecture, and the decorative arts in the middle ages.

Considerations of the study show the extent to which architects and artisans, based on the teachings and instructions of physicians, dealt with the structural and content adaptation models of architecture and decorative arts to human organism and nature.

Keywords: architecture, medical sources, medieval era, nature, wall paintings

\title{
Wpływ architektury i sztuki dekoracyjnej na zdrowie w społeczeństwach muzułmańskich w średniowieczu w oparciu o źródła
}

\begin{abstract}
Abstrakt
Niniejszy artykuł ma na celu przedstawienie historycznego przeglądu wpływu architektury i sztuki dekoracyjnej na zdrowie i zachowanie zdrowia w społeczeństwach muzułmańskich w średniowieczu.

W oparciu o podstawowe źródła medyczne, artykuł ten przedstawia historyczną interpretację teoretycznego pochodzenia ignorowanego związku między medycyną a architekturą (i sztuką zdobnicza).

Nasze odkrycia wskazuja, że niektóre wyniki empiryczne, dotyczące wpływu i aspektów środowiska zbudowanego (przestrzeni architektonicznej) na zdrowie i leczenie - zarówno fizyczne, jak i psychiczne - zostały uwzględnione w źródłach medycznych.

Praktyczne wskazówki z tych źródeł wprowadziły dwa teoretyczne osiagnięcia: 1) wprowadzenie do historycznej wiedzy o zdrowiu środowiskowym i projektowaniu zdrowych miejsc oraz 2) porównawczą analogię środowiska zabudowanego i natury (organizmu) człowieka, która stała się podstawą teoretyczną związku między naukami przyrodniczymi, architekturą i sztuką zdobniczą w wiekach średnich.
\end{abstract}


Rozważania pokazują, w jakim stopniu architekci i rzemieślnicy, opierając się na naukach i instrukcjach lekarzy, zajmowali się modelami strukturalnego i merytorycznego dostosowania architektury i sztuki dekoracyjnej do organizmu i przyrody.

Słowa kluczowe: architektura, historycz̧ne źródła medyczne, średniowiecze, natura, malarstwo ścienne

\section{Introduction}

Preliminary knowledge of the impacts of the natural and built environments on health and treatment is deeply rooted in ancient sources. There is a long tradition saying that healing powers may be found in the physical environment, whether this entails materials such as medicinal plants, fresh air, magnificent scenery, or architecture. ${ }^{1}$ Similarly, the beneficial and effective role of architecture, decorative arts, restorative gardens, and healing herbs in health and treatment appear to be prominent in Asian and Western cultures. ${ }^{2}$ Although space, place, and environment are popular themes in the history of medicine, there are few historical pieces of research on the theoretical bases of the influences of natural and built environments on health and well-being in classical and medieval times, especially in the Muslim society. For instance, The Fourth Factor ${ }^{3}$ by John M. Currie addresses a historical overview of the relationship between medicine and architectural design. He investigates Egyptian, Greek, and Roman practices and forms in ancient and medieval times. Moreover, the key concept of the book Medicine and Space is to consider the relationship between spatial conceptions and medicine. 'The most significant contribution this volume makes is in widening the theoretical understanding and definition of medical spaces. ${ }^{34}$

Although the interdisciplinary relevance of medicine and fields like architecture, garden or landscape design, and the decorative arts has a lengthy history in the West, there is little historical research about the theoretical origins and concepts of this interdisciplinary field. Such interdisciplinary research has so far eluded attention in medical history,

1 Gesler 1992, p. 736.

2 Ulrich 1995, p. 73.

3 See Currie 2007.

${ }^{4}$ Land, Baker, Nijdam 2012, p. viii. 
particularly in the Muslim society during the medieval era. Indeed, in the studies on this interdisciplinary field, scholars have neglected medical tradition in the Muslim society. However, most researches have been focused on the history of the hospital and public baths and their relation to medicine. ${ }^{5}$

After the decline of Byzantine civilization in the $7^{\text {th }}$ century, ${ }^{6}$ this interdisciplinary field primarily became a collection of descriptions obtained from practical cases and lacked a body of knowledge due to the lack of substantial progress in European medical science at least till the $12^{\text {th }}$ century A.D. ${ }^{7}$ Among these, monastic settings are the most well-known cases of restorative gardens in the Middle Ages. ${ }^{8}$ Here, the question arises: What kinds of theoretical evolution happened in this interdisciplinary field in this time and during the Middle Ages? Although scholars have not addressed this question directly, existing medical texts provide extensive information about the continuation and progression of medicine from Greco-Roman heritage to the Muslim society9. Currently, many medical texts in relevant branches of physical [tibb al-jismānī] and psychological (or spiritual) medicine [tibb al-rūhānī] have been surveyed, edited, and published. In these texts, there is much evidence of the theoretical basics of this interdisciplinary field, although many have not yet been scrupulously surveyed or interpreted.

In this paper, we pose two questions. Firstly, regarding the Muslim society from the $8^{\text {th }}$ to $15^{\text {th }}$ centuries A.D., what was the relationship between architecture (and decorative arts) and medicine, and secondly, what were the philosophical and medical foundations upon which the formation of architecture and decorative arts was based? To answer these questions, based on medical sources, we present a historical interpretation of the following:

5 See Dols 1987; Tabbaa 2003; Ragab 2018.

6 Timothy 1997, p. 207.

${ }^{7}$ Rethinking the treatment of the mentally ill and new therapeutic approaches based on the comprehensive connection with nature began at the hospital at Saragossa, Spain, founded in 1409 (Marcus et al. 2014, p. 8).

${ }^{8}$ Saint Bernard $\left(12^{\text {th }}\right.$ AD.) wrote a definitive description of the purposes of these gardens based on one of these cases (Gerlach-Spriggs et al. 1998, p. 9).

${ }^{9}$ Siraisi 1990, p. xi, 1, 13. 
1) The role of medical theories and instructions in architectural design and creating artistic works;

2) Impacts of architecture and decorative arts (wall paintings) on health and treatment.

In the following sections, we describe how medieval physicians paid attention to the effective environmental factors and grounds of health and treatment (both physical and mental). However, two points should be clarified here. Firstly, the present study is a preliminary step towards a brief history of the interdisciplinary relationship between medicine and the fields of architecture and decorative arts. Secondly, we focus on some cases of architecture, as well as landscape architecture, and wall paintings from the perspective of medieval theories of medicine and natural sciences. It is expected that the study of these ignored topics can fill a part of the gap in the historical background, including the intermediary link between the theoretical origins of medicine and architecture (and decorative arts) in the Muslim society during the medieval era.

\section{Architecture for physical health}

The written history of the relationship between medicine and architecture, at least in the West, traces back to the oldest monograph on architecture. According to Vitruvius, 'the architects should also have knowledge of the study of medicine on account of the questions of climates, air, the healthiness and unhealthiness of sites. For without these considerations, the healthiness of a dwelling cannot be assured'..$^{10}$ These words are clearly influenced by the teachings of Hippocrates in the treatise On Airs, Waters, and Places concerning the natural environment's impact on health and illnesses which were described in medical texts later on.

Ancient medicine focused on recognizing human characteristics and components (humors and temperaments), and its main purpose was to protect health (prevention) or to restore health of an ill person. ${ }^{11}$

${ }^{10}$ Vitruvius 1914, p.10.

11 Galen 1977, p. 11; al-Tabarī 1928, p. 6; al-Rāzī 2005, p. 64; al-Mağūsī Ahwāzī 2009, p.19; al-Akhawainī al-Bukhārī 1965, p. 16; Avicenna 1999, p. 13; Jorjāni 2014, p. 61. 
Since medical sciences (Tibb) were related to natural philosophy, they were profoundly influenced by the theory of corresponding similarities of humans and the cosmos (microcosm vs macrocosm). In this theory, 'man produces in miniature all the features of the universe. ${ }^{12}$ Based on this comparative theory, the human body is likened to nature, a city, or a house in many philosophical texts. ${ }^{13}$ Therefore, this theory should be expected to explain some common theoretical origins of natural philosophy and architecture and to reveal the hidden aspects of medieval texts in locating, orientating, organizing, and designing effectively built environments like houses, bathhouses (and murals), hospitals, and cities for health and treatment of illnesses.

One important result of this comparative theory is the hypothesis of quadruple fundamental elements or common constitutive components of nature and human organism that were the basis of ancient medicine. It is said that the four primary elements that constitute nature - namely fire, air, water, and earth - were proposed by Empedocles and accepted by Plato, Aristotle, and later by scholars of Muslim societies. ${ }^{14}$ Each of these elements corresponds to two compound qualities (nature): fire (warm \& dry), air (warm \& moist), water (cold \& moist), and earth (cold \& dry). The Hippocratic system of medicine, accepted by physicians in the Middle Ages, is also based on the quadruple humors (humorism) that have the same temperaments as the quadruple elements. Human temperaments and humors also have the same simple or compound natures (warm/cold/moist/dry). ${ }^{15}$

Following the Galenic tradition, also adopted in the Muslim society, the balance of humors was regarded as the key to human health. In Galen's view, disease happened when humors become imbalanced, and curing the illness was the result of restoring balance to the humors or body. Health protection relies on human harmony with nature and climate. Indeed, ancient physicians often recommended that a patient should act against the climatic conditions to keep or restore the balance

2 Elgood 1951, p. 20.

13 Al-Fārābi 2003, p. 28; Ikhwān al-Ṣafā' 2005, p. 321. Nasr has an extensive account of the holy and universal status of the human body and its relation to architecture. See Nasr 2007.

${ }^{14}$ Lindberg 2007, p. 44.

15 Ibid., p. 16; Jorjāni 2014, p. 74. 
of humors. This recommendation is based on the principle that restoring the balance of humors or curing illnesses was feasible with the opposition (principle of cure by opposites ${ }^{16}$ ) of temperamental conditions.

In the following section, we address the instructions of medical texts in two architectural fields that inspired the most discussions regarding medicine: firstly, the most significant setting for human life - that is, housing and healthy ways of life, based on human harmony with the climatic environment; and secondly, the effects of bathing and bathhouse or public bath [hammām] on health and treatment of illnesses.

\subsection{Housing in medical sources}

Instructions concerning human interaction with the climate in housing (and urban housing) have been discussed from the viewpoint of medical theories and purposes under the title: "The medical planning of residential environments" [i.e., tadbīr al-masāken]. It has been said that both change and the harmony of human ways of life with climatic changes in the environment are an important part of the theoretical foundations of ancient medicine for sustainable health. This harmony requires that the housing environment has the possibility to change different conditions of human life to restore moderation. In fact, by following the principle of appropriate 'change' in 1) the way of life, and 2) the built environment, traditional people tried to modify the climatic conditions of their environment to balance the temperaments. These changes were noted in different forms in medical sources, as shown below, but only the change of location will be discussed due to its importance to this study:

1) change of diet, clothing, and activities in the four seasons;

2) change of location (movement) on a regional, or a city-wide scale, or within a house;

3) flexibility and multi-functionality of housing spaces;

4) flexibility of the components of housing spaces.

Temporary change of location or, equivalently, 'movement', was one of the ways to live a life compatible with the climate to provide an

16 Yin and Yang is a fundamental concept of duality and opposites in Chinese medicine, see Maciocia 2015, p. 11. 
environment suitable for human health. The movement had been the most conventional approach to selective adaptation with natural and built environments in the ways of life both for animals and humans before active energy systems in buildings were developed. Moving within the house (a seasonal division of house parts) was described by Abū Zayd Balkhī (850-934) ${ }^{17}$ (see fig. 1). The movement was so important that physicians exploited the same patterns of changing the location and the way of life in the treatment of some diseases and in restoring health through relocation (i.e., climatotherapy). Climatotherapy, which traces back to Hippocratic medicine, ${ }^{18}$ refers to relocating the patient to a more suitable climate. Indeed, besides the therapeutic purposes, this approach to climate was a common way to preserve or improve health. ${ }^{19}$ Climatotherapy is based on the belief that the most important practice for health preservation and treatment of some diseases is to change the temperament condition of humans by changing the climate, especially the air ${ }^{20}$ as the first essential factor of health to provide a balance between human temperaments and the climatic environment. ${ }^{21}$

The element of 'air' (wind) and its ventilation, as described in medical texts, was the most important factor affecting the formation of housing environments. In these texts, the characteristics of healthy and unhealthy places were investigated and analyzed by considering various aspects, such as geographical coordinates, topography, wind directions and exposure to them, and proximity to mountains, seas, marshes, and types of soil. ${ }^{22}$ Among these, geographical position and directions of houses, and types of wind directions, were the most important factors in locating and organizing housing and cities. In addition to identifying appropriate geographical direction as the most important factor, other causes for the quality of the winds were noted, such as the sources or wind paths

17 Abū Zayd Balkhī 2005, p. 357.

18 Hristakieva 2005, p. 27.

19 Vitruvius 1914, p. 15; al-Harrān̄̄ 1928, p. 165; al-Rāzī 2005, pp. 74, 175; Jorjāni 2014, vol. 2, p. 37; al-Masihi 2000, p. 114.

${ }^{20}$ Jorjāni 2005, vol. 1, p. 201.

21 Adams 1886, p. 190; Galen 1977, p. 23; al-Rāzī 1987, p.163; 2005, pp. 73-74; al-Mağūsī 2009, vol.1, p. 201.

${ }^{22}$ Abū Zayd Balkhī 2005, p. 351; al-Rāzī 1987, p. 163; al-Mağūsī 2009, vol. 2, p. 30; Avicenna 1999, vol. 1, p. 129; Jorjāni 1990, p. 18; 2005, vol. 1, p. 205; 2014, vol. 2, p. 51; al-Masihi 2000, p. 113; Ibn Hubal 1943, vol.1, p. 109. 


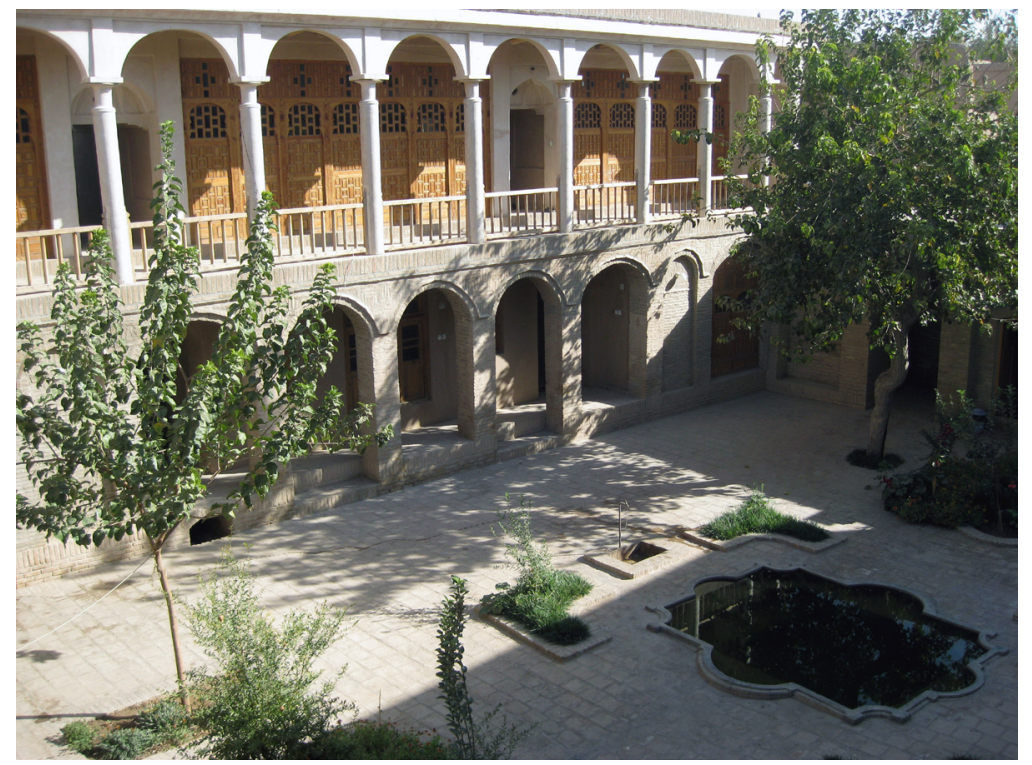

Fig. 1.1: Attarbashi house. Herat, Afghanistan. Winter north wing. 50007 (C) Aga Khan Trust for Culture / AKCS-A (photographer)

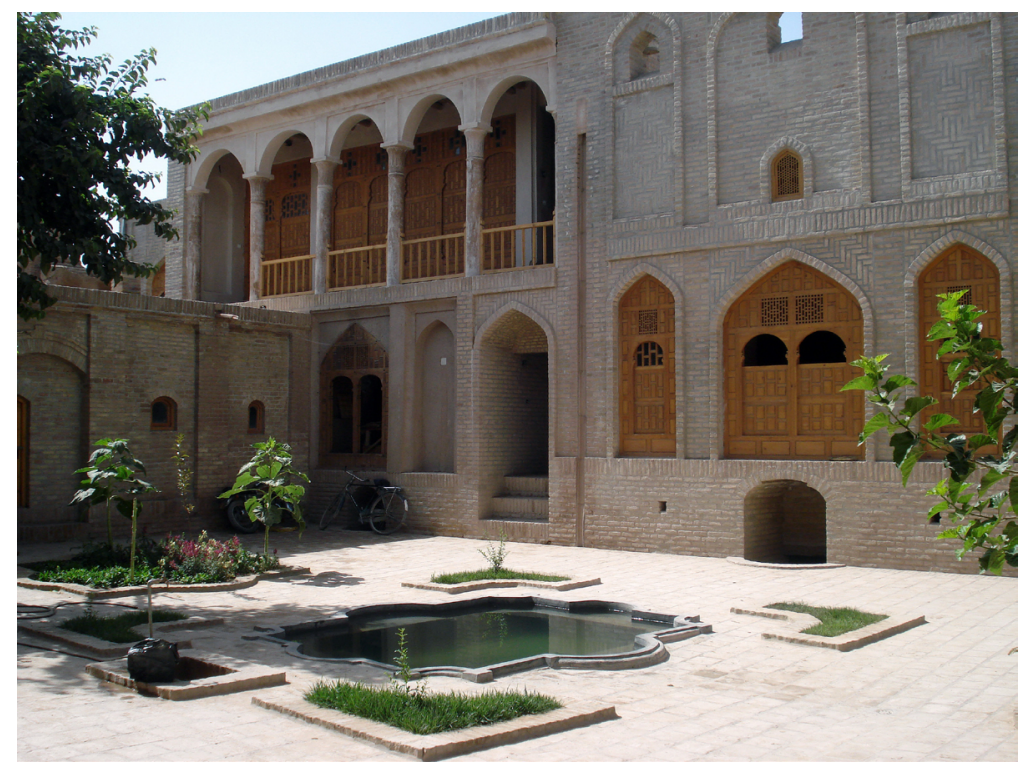

Fig. 1.2: Attarbashi house. Herat, Afghanistan. Summer south wing. 50014 (C) Aga Khan Trust for Culture / AKCS-A (photographer) 
in unhealthy regions, marshes or harmful plants. ${ }^{23}$ Following Hippocrates in studying the locations and directions of cities and houses, physicians in the Muslim society thought of the east (due to its moderate winds) and north directions as beneficial for health, while the western and southern directions (because of their warm winds) were regarded as improper. ${ }^{24}$ In fact, a particular emphasis in the medical texts placed on these directions refers to the nature of winds in these regions, i.e., moderate (east winds) and cold/dry (north winds) - compared to other directions and considering the concurrent effect of quality, temperature and humidity of air - as well as to the beneficial effects of moderate and cold air on body invigoration, health and treatment. ${ }^{25}$ However, prior to this approach and under the influence of Hippocrates's instructions about the location and construction of cities, Vitruvius pointed to the importance of geographical directions, the helpful east and north winds and the impact of these elements on human health. Vitruvius mentions temperate climate and positioning as essential conditions in choosing a city location and the directions of the streets, and remarks on the wind's effects on health (hygiene) ${ }^{26}$ For instance, in hot-humid climates like Bushehr (Iran) and Manama (Bahrain) "the predominantly northwesterly wind of the region, known as the north [shamāl], blew through these streets and so reduced the effects of the long hot and humid summer. ${ }^{27}$ Shade was achieved through narrow and winding streets." ${ }^{28}$ Although, researchers believe that parameters like water and climatic factors - especially exposure to pleasant winds and avoiding unpleasant ones - were among the major factors in the construction of cities and houses in the Muslim society, ${ }^{29}$ investigating the size of the effects of medical instructions on architecture requires comprehensive research.

23 Taheri 2014 p. 30.

${ }_{24}$ Adams 1886, p. 194; al-Rāzī 2000, p. 414; Jorjāni 1990, p. 18; 2005, vol. 1, p. 205; Avicenna 1999, vol. 1, p. 129; al-Masihi 2000, p. 113; al-Ruhāwi 2008, p. 51; Ibn al-Jawzī 2010, p. 229; Ibn Hubal 1943, p. 111; al-Teflisi 2011b, vol. 1, p. 51.

25 Taheri 2014, p. 30.

${ }^{26}$ Vitruvius 1914, pp. 17, 24.

27 More interestingly, in one of the few treatises on architecture (Indian sub-continent, $19^{\text {th }}$ century A.D.) geographical directions of north, east, west, and south (order is important) are prescribed for house construction. See Bannā 2014, p. 46.

${ }_{28}$ Elsheshtawy 2008, p. 188.

${ }_{29}$ Bianca 2000, pp. 31, 45; Kheirabadi 2000, p. 34; Raymond 1985, pp. 84, 91. 


\subsection{Bathhouse in medical sources}

Besides having ritual, social and hygienic functions, bathing in ancient times was one of the oldest ways to prevent, and occasionally treat, physical and mental disorders. That is why bathing in a traditional society was considered one of the most important interdisciplinary subjects of architecture and medicine, described in many medical sources. ${ }^{30}$ These texts claim that ancient philosophers who created the concept of the bathhouse [hammām] used the theory of 'similarity between human and nature' in the structure and organization of this type of architecture for medical purposes. ${ }^{31}$ In addition to the advantages and disadvantages of bathing to health and treatment, physicians also identified general characteristics of a public bathhouse, such as bright and large spaces, fresh and steam-free air and, above all, gradual changes of temperature by organizing the sections of the bathhouse. In fact, experience and medical science indicated that, apart from advantages such as cleanliness, refreshment, body recovery, and relief from pain, bathing in such bathhouses provided a ground for a gradual return of balance to body and soul. This balance was based not only on traditional processes of bathing, but also on two artistic elements: 1) conformity of structure in different parts of a bathhouse to human temperaments, and 2) conformity of the themes in internal wall paintings (murals) of bathhouses that were linked to the three spirits or Nafs [pneumas]. Here, we address the first conformity, and, in section 3 , we discuss the second.

The oldest structural comparative model of bathhouse architecture based on temperaments or humors is described in an Arabic treatise on medicine from the early $9^{\text {th }}$ century, 'al-Risäla al-Dababiyya fil Tibb' (The golden treatise on medicine), attributed to 'Alī ibn Mūsā ar-Riḍā (765-818). In the treatise, the following instructions are provided: ${ }^{32}$

30 Among the early texts about bathing, we can refer to the book On entering the bathhouse and its benefits and harms written by ibn Māsawaih (died: 857 AD.), Risalah fi al-hammām [Treatise on bathhouse and its benefits and harms] by al-Rāzi, and the book Bathhouse by Qusțā b. Lūqā al-Balabakki (840-912), Ibn Abī Uṣaybi‘a 1956, p. 475; Balkhī 2005, p. 44.

31 Taheri 2016, p. 48.

32 All translations are made by the author except where otherwise noted. 

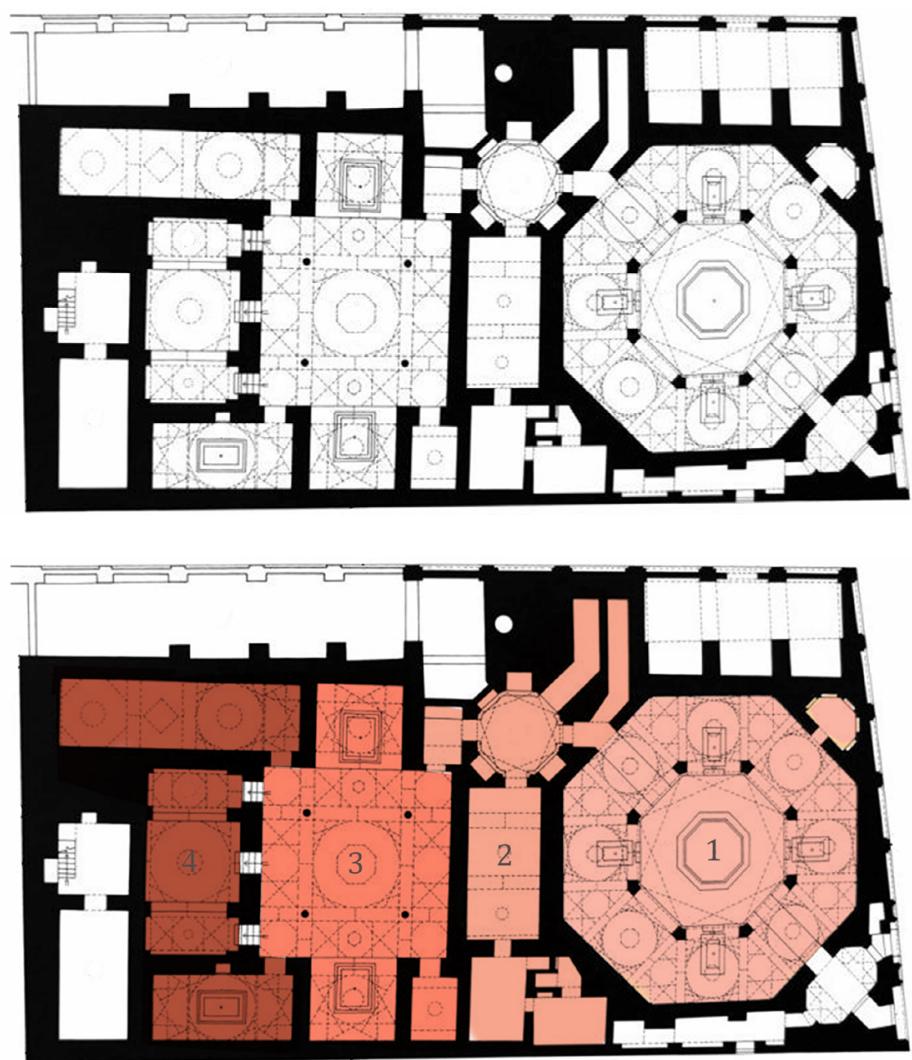

Fig. 2: Four basic sections of Vakil bathhouse (c. 1760). Shiraz, Iran.

Be aware that the bathhouse structure (combination) is based on the structure of the human body. A bathhouse has four rooms (sections), and these rooms are like human temperaments: the first room is cold and dry; the second is cold and moist; the third is warm and moist; the fourth is warm and dry. ${ }^{33}$

Later, several physicians in the Muslim societies dealt with this comparative analogy and quadruple structure of bathhouses. ${ }^{34}$ However,

33 Al-Dhahabiah 1982, p. 30.

34 Al-Dimašqī 2009, p. 119; al-Mağūsī 2009, vol. 2, p. 51; Ibn Butlān Baghdādī 1987, p. 142; Ibn Hubal 1943, p. 210; Karīm ibn Ibrāhim 2008, p. 4. 
another group of physicians interpreted the treatise differently regarding the number of sections in a bathhouse, based on the triple hierarchical system of temperature, although these interpretations are conceptually the same. ${ }^{35}$ In fact, the three temperature levels (cold, tepid, warm) in the approach of Romans to naming the bathhouse sections in the Muslim society may have been taken from the instructions of physicians.

The Umayyad bathhouses were developed based on the Greek [Therma], Roman, and Byzantine public baths. ${ }^{36}$ The major spaces of bathhouses in western Islam, ${ }^{37}$ such as the Roman baths described by Vitruvius, ${ }^{38}$ consisted of four sections: 1) Undressing room [Apoditerum], 2) Frigid room [Frigidarium], 3) Tepid room [Tepidarium], and 4) Stove hall [Caldarium]. Bathhouses in Cairo, which were designed through imitation of Roman bathhouses, comprised four basic sections: 1) Undressing room, 2) First house (first stove hall), 3) Second house (hot room), and 4) Third house (steam room [Roman laconicum]). ${ }^{39}$ Bathhouses in Persia were also divided into four (or three, if the last two sections were integrated) basic sections, including 1) Undressing room, 2) Middle hall [sarbīneh], 3) Stove hall (hot room), and 4) Kazina [xəzinə]. (see fig. 2)

Based on the above interpretations, the architecture of bathhouses includes four qualities or temperaments in four sections and also creates gradual hierarchies of temperature, first entering cold spaces and then progressing to warmer ones and vice versa, to balance the body temperature. ${ }^{40}$ Most of the three-section bathhouses, based on the triple hierarchy of temperature, are made into four-section bathhouses by taking the undressing room or Kazina (xəzinə) into account.

A theoretical model that compared the quadruple structure of bathhouses with the four temperaments in al-Risalah al-Dhababiah - when bathhouses still followed the hierarchical temperature model - was considered to be a new medical interpretation of the relationship between medicine and architecture. In this model, the same structure

35 Avicenna 2008, p. 24; Averroes 2005, p. 414; al-Hamawī 1987, p. 139; Malek-al-Ațebbā' 2009, p. 146.

36 Papadopoulo 1989, p. 106.

37 Barrucand, Bednorz 2007, p. 260.

38 Vitruvius 1914, pp. 157-159.

39 Behrens-Abouseif 1989, p. 43.

${ }^{40}$ Taheri 2016, p. 52. 
of bathhouses - undressing room plus the triple temperature forms was aligned with the four temperaments through the combination of two qualities: dryness and moisture. In this way, a better theoretical model was presented for hygienic and medical purposes, indicating the relationship between the four temperaments and different sections of bathhouses in Muslim societies during the medieval era.

\section{Architecture, wall paintings, and mental health}

In this section, we show that physicians paid attention to the close relationship of humans with natural/built elements and scenes for better mental health and treatment. Mental health was defined in medical sources as 'medicine of self' (Nafs). In these sources, mental health, like physical health, depends on self-balance and the quality of its interaction with the body and environment. ${ }^{41}$ The triple division of the human self, as described by Greek philosophers, i.e. nutritive soul, animal soul, and thinking soul, was accepted by physicians and transformed into triple powers (quwā), namely physical, animal and psychological. In natural philosophy and ancient medicine, human senses were considered to be the primary instruments of animal and psychological power for movement and perception. These considerations include discussions on mental health concerning head-related diseases (brain), such as melancholia. ${ }^{42}$

Melancholia, or black bile (humor), is a physical disease that can be defined as a specific feeling of depression, loneliness, and illusionmaking. The dominance of the black bile humor destroys perception and creates corrupt thoughts. ${ }^{43}$ Using natural materials, elements, and scenes to create the treatment procedure, as described in medicine, was adopted in psychotherapy. One of the complementary therapies for the treatment of melancholia, in addition to medication, is to encourage the patient to pursue activities that engage their minds and avoid corrupt

${ }^{41}$ Al-Tabarī 1928, p. 60; Abū Zayd Balkhī 2005, p. 357; Pormann, Savage 2007, p. 83.

42 Among the monographs about this field, we can mention the book al-Malikhoolia and its causes/symptoms/treatments by ibn Māsawaih, and Treatise on Melancholy written by Ibn Imrān (10 $0^{\text {th }}$ century A.D.) The latter work was brought to Europe by Constantinus Africanus in the $11^{\text {th }}$ century.

${ }^{43}$ Ullmann 2004, p. 102. 


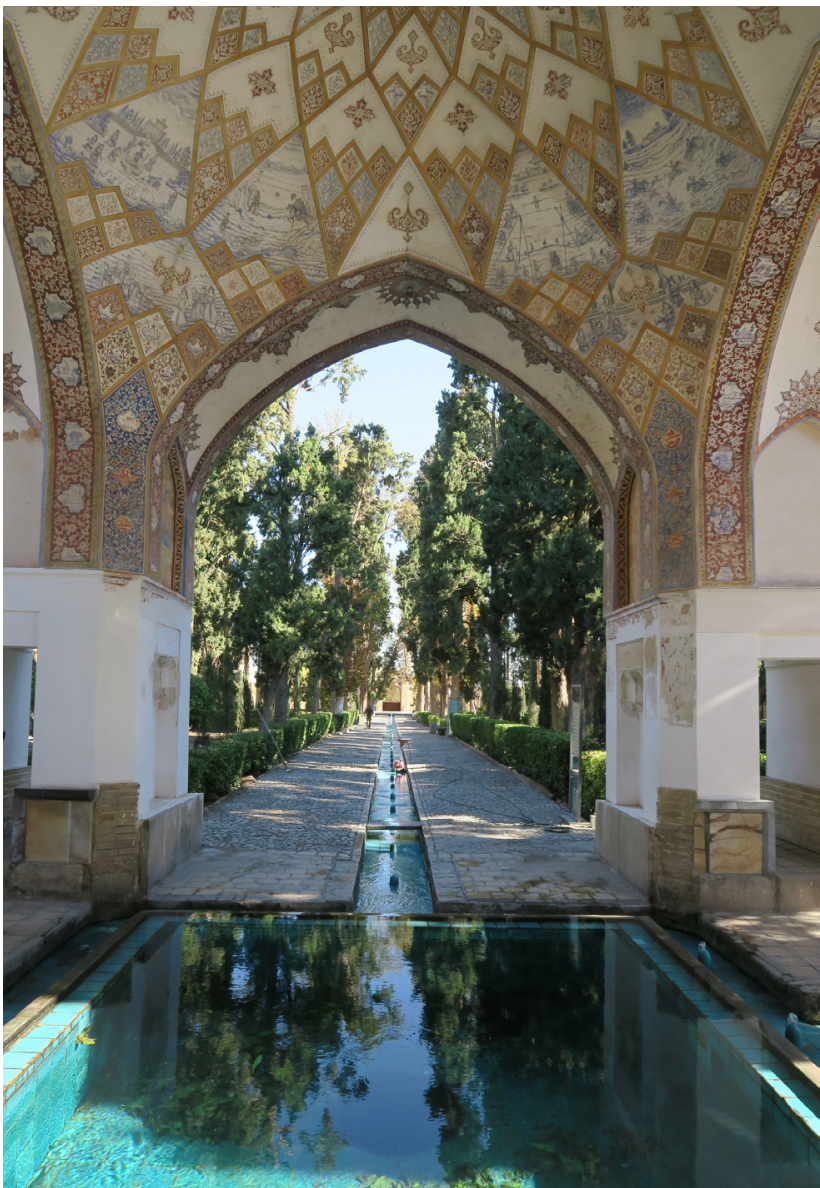

Fig. 3: Bāgh-e Fīn [Fin garden] near Kashān, Iran.

thoughts. Al-Rāzi (c. 854-925), who studied the treatment of this disease, recommended exercising, walking, avoiding loneliness (i.e., finding companionship with others), hunting, playing chess, drinking light wine, listening to music, racing, and long journeys (or moving to a new house), which take the mind away from deep thoughts of the past. ${ }^{44}$ Jorjāni also prescribed a quiet, lively, beautiful, and fragrant environment for the treatment of melancholia. ${ }^{45}$ Avicenna (980-1037) believed that a patient

\footnotetext{
44 Al-Rāzī 2000, vol. 1, p. 60.

45 Jorjāni 2014, vol. 3, p. 295.
} 
suffering from melancholia should be kept happy with fun and good songs, and the patient's room should be mild and moist, with the scents of fragrant herbs. ${ }^{46}$

A review of historical texts indicates that the treatments mentioned above attracted the attention of physicians, not only in the treatment of melancholia but also in most therapeutic, restorative, as well as housing environments. What initially draws one's attention in these texts and their descriptions of the structure of hospitals in the Muslim society, is the establishment of hospitals within a beautiful environment with a good climate and natural scenery, such as the pattern of courtyard gardens (see fig. 4\&5). It appears that incorporating these qualities into designing hospitals for medical purposes was actually preferred over the buildings' functions. ${ }^{47}$

Physicians did not ignore the natural views and good atmosphere of the indoor spaces. For example, in addition to trees, plants and streams in hospitals to improve the atmosphere and environment around a patient (see fig. 4), al-Isrāîli (855-952) recommends that the window of a patient's room should be open so the patient can have access to natural ventilation and scenery: 'Rooms should be strewn with aromatic plants like sandals and rosewater. Also, running fountains should be installed in front of the patient so that he may listen to the gentle fall of water; for the splash of water, if light and gentle, will induce sleep'(see fig. 6)..$^{48}$

Additionally, the importance of locating and establishing hospitals in the healthiest places in terms of soil, climate, proximity to gardens, and natural views could have at least three reasons from the medical perspective.

1) Until the advent of modern medicine in the West, fresh air for health and treatment in traditional medicine and therapeutic environments was considered to be priority.

2) The need for medicinal plants provided the basis for the close relationship of agriculture and botany with medicine and pharmacology. Therefore, physicians usually paid attention to these plants in their

46 Avicenna 1999, pp. 129, 133.

${ }^{47}$ For further reading about locating the hospitals in a good climate and natural scenery see İsá Bak 1981.

48 Pormann, Savage 2015, p. 46 


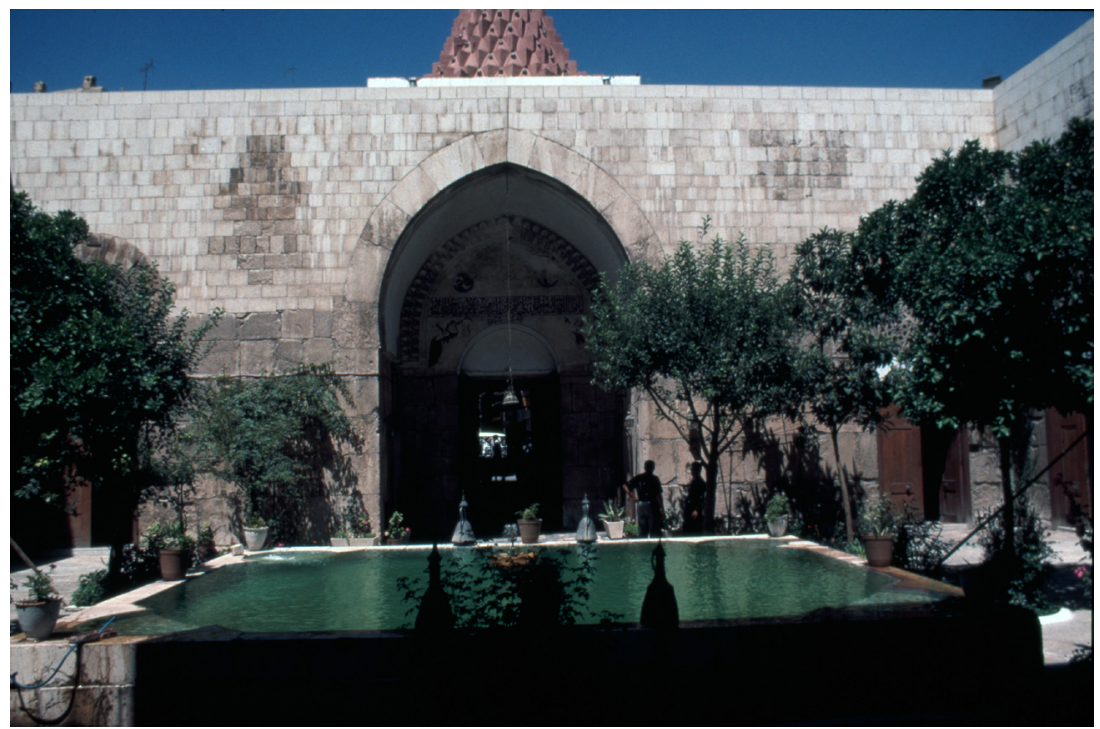

Fig. 4: View of Main Courtyard, Bimaristan of Arghun al-Kamili (1354), Aleppo. (Yasser Tabbaa Archive, courtesy of Aga Khan Documentation Center at MIT).

works, and some works on agriculture are attributed to physicians. There is even some evidence that the gardens of Andalusian hospitals were used as botanical laboratories and that some physicians participated in the gardening process. ${ }^{49}$

3) The benefits of a relationship with natural outdoor spaces in health and psychotherapy, emphasized by the majority of physicians, was

49 The book Fi al-Falähät [Total in agriculture] on agriculture and botany is attributed to Ibn Wāfd (997-1074), a physician and pharmacist from Andalusia. It is said that he was the head of the botanical garden in Toledo. Another treatise entitled Al-mukhtasar Kitäb al-Falähät [The compendious book on agriculture], attributed to Abū ăl-Qāsim Halaf b. 'Abbās al-Zahrāwi remained. One of the most systematic treatises on Andalusian agriculture entitled Zahr al-bustān wa-nu乏̧hat al-aḍhān belonging to Muhammad b. Mälike al-tignari $\left(11^{\text {th }}-12^{\text {th }}\right.$ AD.), and the book called 'Umdat al-tabīb fí Ma' rifat al-Nabāt [Botanical dictionary] written by Abū l-Khayr al-Ishbīlī $\left(12^{\text {th }}\right.$ century A.D.) are about topics such as botany and medicine (see Siraisi, Medieval and Early Renaissance Medicine, p. 142, and Sánchez 1992. It is also worth mentioning other agricultural books such as Irshäd al-Zira'ah [Guidance to agriculture] by Qāsim b. Yusuf al-Harawi (16 ${ }^{\text {th }}$ century A.D.) and Mafatih al-Arzaq [The keys of livelihoods] by Muhammad Yusuf Nuri (19 th $^{\text {th }}$ century A.D.), which pointed to the medical properties and benefits of various plants. 


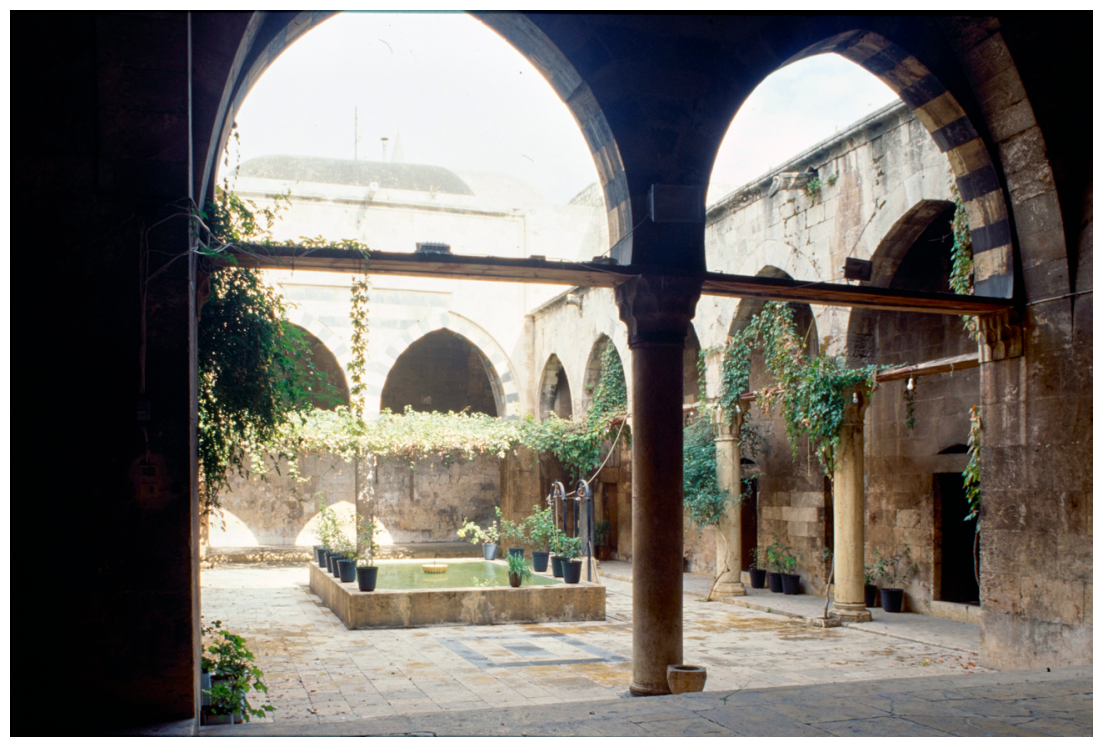

Fig. 5: Courtyard view with fountain and dome, Bimaristan Nur al-Din (1154), Damascus. (Nasser Rabbat, courtesy of Aga Khan Documentation Center at MIT).

described by Rashīd al-dīn faḍlullāh hamadānī (1247-1317), a physician, politician, and historian:

The perception of the five senses naturally stops functioning when the temperaments become unbalanced. For this reason, physicians have prepared buildings in beautiful and pleasant places with good climates to solve this problem. ${ }^{50}$

The evidence described above provides a theoretical background: 'there is a long tradition that healing powers may be found in the physical environment, whether this entails materials such as medicinal plants, the fresh air and pure water of the countryside, or magnificent scenery'. ${ }^{51}$

Wall paintings: The beneficial effects of decorative arts in treating mental illnesses or in the improvement and promotion of (physical) health can be traced to ancient civilizations. Even physicians considered amusement, fun, and pleasure, which are among the purposes of the

${ }^{50}$ Rashīd al-dīn F. Hamadānī 1945, p. 251.

51 Gesler 1992, p.736. 


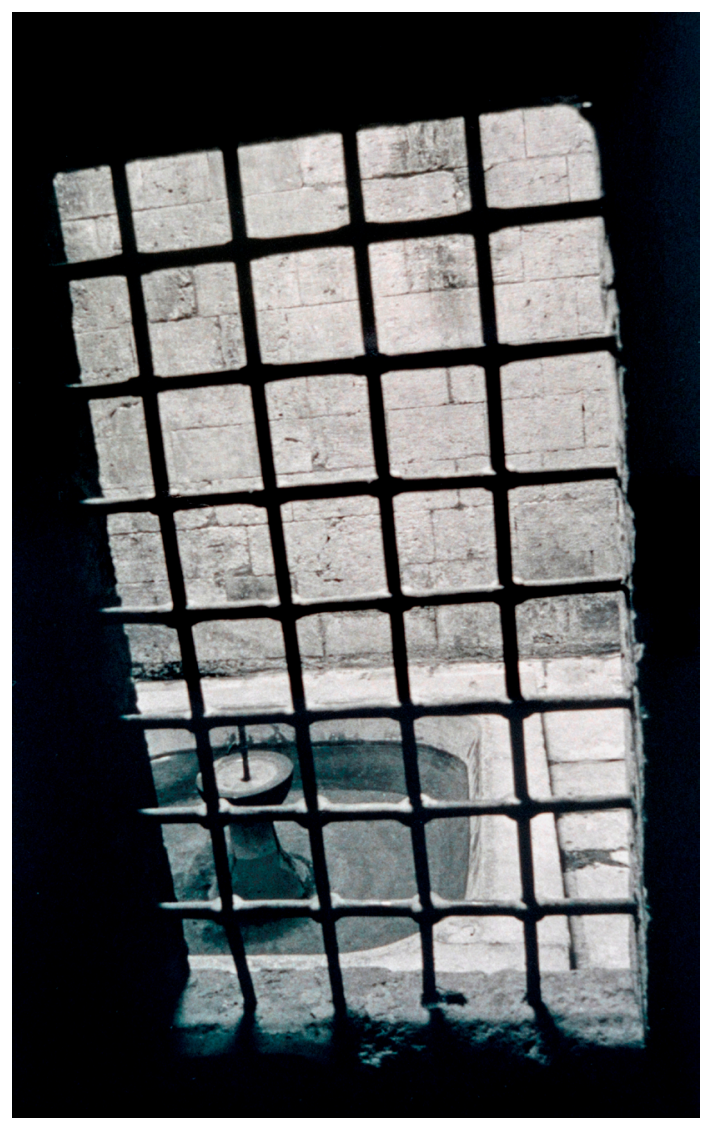

Fig. 6: View from one of the chambers of the insane to an open courtyard at Bimaristan of Arghun al-Kamili (1354) (Tabbaa 2003), Aleppo. (Yasser Tabbaa Archive, courtesy of Aga Khan Documentation Center at MIT).

arts, to be necessary conditions for mental recovery, health preservation, reinforcement of human strength, and disease avoidance. Philosophers and physicians believed that without the arts people risked weakness and lack of physical endurance. ${ }^{52}$ To achieve these purposes, more than a thousand years before recent evidence-based approaches, physicians were aware of the beneficial effects of decorative arts like paintings and wall paintings on the process of health preservation and treatment (art therapy) despite the religious sanctions related to these arts in Islam.

52 Jorjāni 2014, vol. 2, p. 461. 
Here, concerning the therapeutic dimensions of wall paintings in the Muslim society, we should point out that these arts have long been accompanied by social ceremonies, including storytelling, poem reading, and narrating in medical and restorative environments; these issues were not ignored by physicians. Al-Rāzi and Malek-al-Ațebbā' knew that strengthening verbal skills and mirth, especially spiritual mirth, by hearing anecdotes and jokes, respectively, was one of the benefits of a bathhouse for one's social and psychological health. ${ }^{53}$ The purposes of these ceremonies include 1) accelerating the treatment of diseases ${ }^{54}$ in hospitals, and 2) (in bathhouses) relaxing from job troubles and tensions as well as creating a quiet social environment for the restoration of physical, intellectual and psychological powers.

Painting was considered to be one of the most important environmental tools and stimuli effective in the treatment and promotion of mental health. Painting and decorating inspired by nature (concrete and abstract) in the Muslim society, ${ }^{55}$ apart from improving the quality of therapeutic and restorative environments, has been a part of the treatment process and health preservation for centuries. Recent empirical studies see the use of simulated nature views as a substitute for natural elements to influence the treatment process, reduce costs, and improve recovery outcomes. ${ }^{56}$ An overview of some medical sources shows that painting had important treatment outcomes, such as an increase in environmental quality, feelings of pleasure, restoration of energy, promotion of health, and acceleration of the treatment of mental and physical illnesses. Hunayn ibn Ishāq $\left(9^{\text {th }}\right.$ century A.D.), the most prominent translator of medical Greek texts into Arabic, remarks: 'the ancient philosophers agreed that the presence of paintings in children's room makes their hearts happy by looking at paintings, and this encourages them to learn more and stay longer in the classroom'. ${ }^{57}$ Badrūddin Muzaffar Qādi $\left(13^{\text {th }}\right.$ century A.D.), a physician, says in Mufrrih al-nafs (The gladdener of the Soul) that 'all philosophers and physicians believe that looking at beautiful and magnificent

53 Al-Rāzī 1987, p. 146.

${ }^{54}$ Jorjāni 2014, vol. 2, p. 46.

55 Ettinghausen, Grabar 2001.

${ }^{56}$ Lawson 2010, p. 101.

${ }^{57}$ Ibn Abī Uṣaybi‘a 1956, p.173. 
pictures creates beatitude and ecstasy, effaces melancholic thoughts and obsessions, and strengthens the soul' ${ }^{58}$

Description and analysis of the psychological themes of wall paintings in the bathhouses, and the proportion of this art to the human psychological dimensions, are among the rarest theoretical origins of the creation of decorative arts, as described in medical texts. Most physicians believed that the bathhouse (bathing following the old way) caused weakness in the human body and in its psychological powers. ${ }^{59}$ Based on the principle of treatment with opposites to cure the weakness of the powers, they prescribed creation of natural and realistic pictures with themes proportional to the nature of each of the powers to strengthen them, and thus restore the balance of temperaments. It was believed that these pictures would provoke and increase the psychological powers first, and then the physical powers. Here, like the conformity and correspondence of the bathhouse sections with the temperaments, the emphasis is on conformity and correspondence in the themes of bathhouse paintings with the characteristics of the triple powers, namely natural (physical), animal, and psychological. According to alGhazūlī (15 $5^{\text {th }}$ century A.D.),

For those who have evil thoughts and corrupt temptations that are contrary to the natural order of things Zakariyyā alRāzī says: "Certainly, beautiful pictures, when formed from a combination of conventional colors like yellow, red, green and white, can heal black bile (melancholia). Therefore, the discomfort and distress or gloom in the human soul are removed because the soul has become delicate through looking at such pictures, and the distress or darkness in it is thus removed." The ancient philosophers discovered that a great part of human powers diminishes when entering the bathhouse. Their wisdom enabled them to correct the problem quickly with the help of wisdom and wit; thus, pleasing and cheerful pictures were painted in bathhouses. These paintings were divided into three groups, which

58 Al-Ghazūlī 1881, vol. 2, p. 7.

59 Al-Harrānī 1928, p. 2; Avicenna 1999, p. 141; Jorjāni 2014, vol. 3, p. 116; Al-Teflisi 2011a, p. 462. 
were placed in different rooms of the bathhouse since the philosophers knew that the body possesses three pneumas (spirits or Nafs), i.e. animal (vital), psychological (psychic), and natural (physical), and each picture should strengthen and increase one of these powers. To strengthen the animal power, the pictures depicted wars, horseback riding, and wildlife hunting; to strengthen the psychological power, the pictures depicted love and thoughts of the lover and the beloved, and pictures of blaming or embracing each other or similar actions; and, to strengthen the natural power, they depicted gardens and beautiful trees with countless pictures of flowers and exciting colors in the bathhouse. Artists paint bathhouses only with these three types of paintings and, if they are asked about the characteristics of the paintings, they cannot explain it because the passage of time has weakened the development and explanation of their foundations and themes. ${ }^{60}$ (see fig. 7)

Al-Ghuzūlī, after mentioning al-Rāzi's descriptions, states that in a good bathhouse there should be 'magnificent pictures of beauties such as lovers and the beloved, gardens, galloping horses, and wildlife. Indeed, in such pictures, there is a strong and perfect strengthening for all powers of the body'. ${ }^{11}$ Later, Ibn Butlān Baghdādī (d. 1064) explained the theoretical foundations of these paintings (knowledge of forms and images):

The powers of lust and anger in humans are both subject to temperament and, because bathing weakens these powers, the walls of bathhouses are painted with pictures that give rise to erotic power, such as parties, and pictures that increase the power of anger, such as wars, were also painted. However, since bathing does not have an effect on the intellectual power of man, there are no pictures that can motivate the intellectual power, such as pictures of wise men and the like. ${ }^{62}$

\footnotetext{
${ }^{60}$ Al-Ghazūlī 1881, vol. 2, p. 7.

${ }^{61}$ Ibid.

${ }^{62}$ Baghdādī 1987, pp. 159-161.
} 


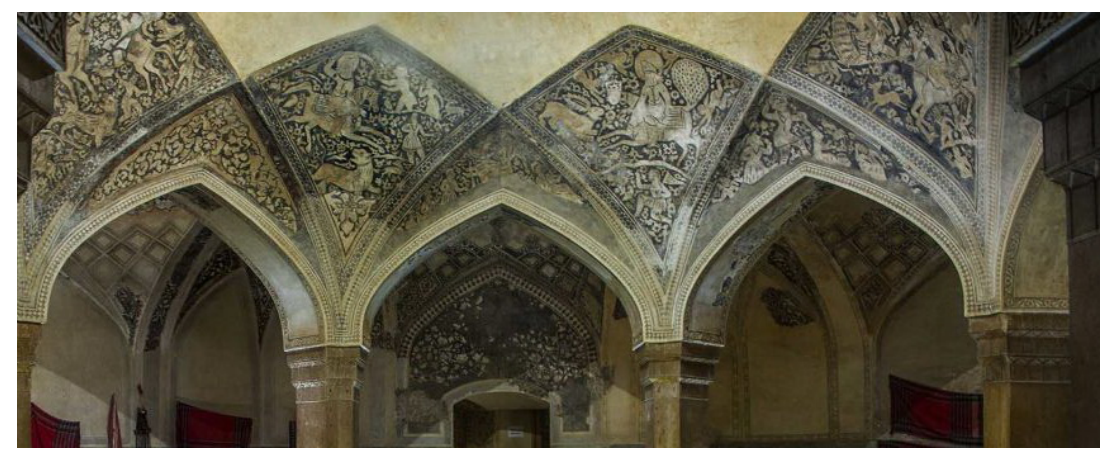

Fig. 7.1: Painting of the ceiling of the undressing room in Vakil Bathhouse (c. 1760). Shiraz, Iran. (courtesy of Karnaval, archived on karnaval.ir)

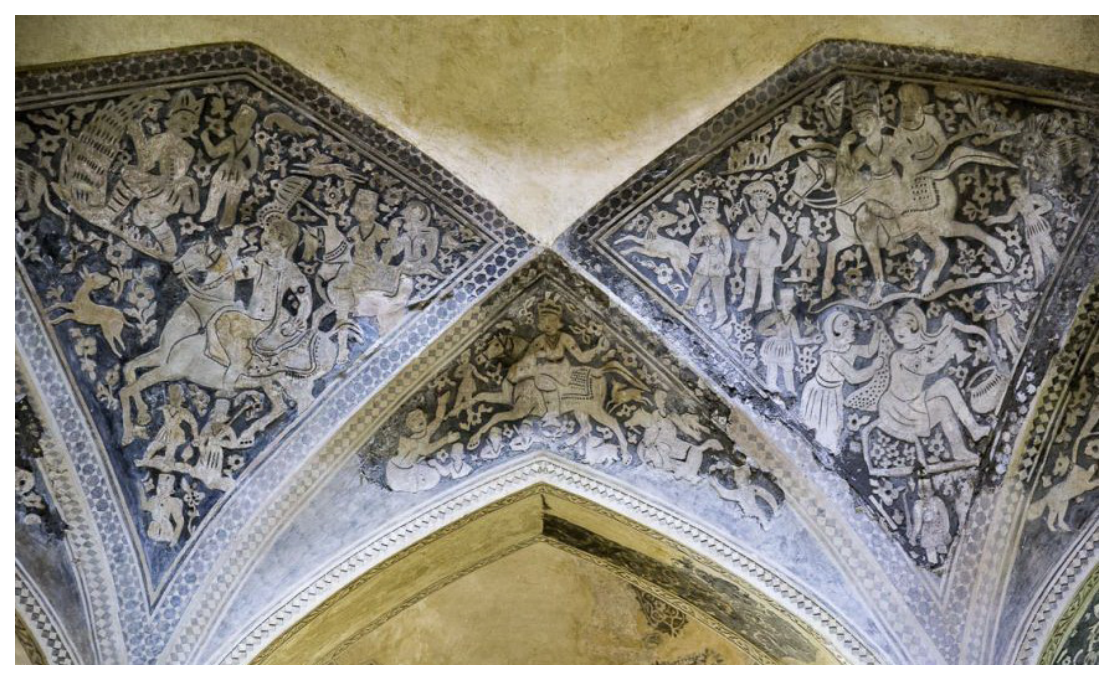

Fig. 7.2: Painting of the ceiling of the undressing room in Vakil Bathhouse (c. 1760). Shiraz, Iran. (courtesy of Karnaval, archived on karnaval.ir)

Later on, the arguments mentioned above were explained in the latest medical text $\left(19^{\text {th }}\right.$ century A.D.). ${ }^{63}$ Finally, if other works of traditional decorative arts are viewed from the perspective of medical teachings, it would not be surprising that throughout the Muslim society in the Middle Ages, artisans and craftsmen used many natural views (both

${ }^{63}$ See Malek-al-Ațebbā’ 2009, p. 154. 
Jafar Taheri

The impacts of architecture and decorative arts on health...

concrete and abstract) in arts and crafts. Even Persian carpets, with amazing abstract paintings of gardens, were an inseparable part of the architecture in houses, hospitals, and bathhouses. ${ }^{64}$

\section{Conclusion}

In this paper, a brief history of the theoretical and practical relationships between medicine and architecture (and decorative arts) in the Muslim society during the medieval era was investigated. Although medical teachings explained and foreshadowed some recent empirical findings based on the beneficial effects of natural views or built environments inspired by nature, the impact of the quality of the interaction between humans and nature (and natural elements) on health has been based on a wide range of structural and content relationships. The key to understanding the interdisciplinary relationship of medicine and the fields of architecture and decorative arts lies in the deep relevance between humans (microcosm) and Nature (macrocosm) and, similarly, between art, architecture, and humans in ancient natural philosophy. The most important aspect of this relationship is the position of humanity in the cosmos and its outcomes in the quality of human interaction with the natural environment and the creation of architectural and artistic works. Using the language of research methodology, it must be said that, in the holistic and hierarchical attitudes of the ancient, nature (as a whole) was the 'independent variable', because nature has priority over parts, and humans and the built environment, as parts belonging to nature, were 'dependent variables'. From this perspective, it is understandable why nature - and, consequently, human organism -has been the theoretical origin of organizing human ways of life in the pre-modern period and designing the built components and environments. In short, based on instructions from medical texts, three fundamental principles regarding human health in connection with the built environment can be derived from the theories of physicians:

${ }^{64}$ There are various reports on the use of carpets in hospitals. For example, in Baghdad's al-'Adudi and Qalāwūn Hospital, beds and carpets were used and water was flowing in most of its halls, see İsá Bak 1981, pp. 71-118. The Hospital of Morroco was also decorated with beautiful woolen, cotton, silk, and leather carpets, see al- Marräkushī 1881, p. 209. 
1) Similarity: Similarity between humans and nature in elements, structure, and rules.

2) Balance: Reliance on the balance of humors and temperaments for human health.

3) Change: Harmony and conformity of humans with the changes in the natural environment for the balance of temperaments.

Based on the above considerations, the physicians in the Muslim society, in both theory and practice, used various forms of conformity and similarity of the whole to the parts of the built environment with the structure and content of nature and human nature (physical and psychological) for the preservation of spiritual and physical health. These similarities and conformities in medical sources briefly related the three concepts of nature, human, and built environment (architecture and art) to each other, resulting in the following three ways to achieve medical purposes:

1) Nature and buman: Conformity and harmony of human ways of life with the principles and changes of nature;

2) Nature and built environment: Structural and content similarity of art and architecture with elements, patterns, and principles of nature;

3) Human and built environment. Conformity and support of art and architecture in the ways of life and human mental and physical structure.

Therefore, the profound relationship between humans and nature in works of art and traditional architecture and art for sustainable health goes beyond the relationship to emotions, similarity (in macroand micro scales), or the application of natural elements and patterns. Hence, we should consider the arts to be compatible with human psychological nature on different scales. For instance, in the visual arts, concrete or abstract themes are chosen based on natural patterns or rules (mathematics) or the structure of nature and human behaviors (physical and psychological). These considerations show the extent to which the architects and artisans, based on the teachings of natural philosophy, dealt with the structural and content adaptation models of architecture and decorative arts with humans and nature.

Two other issues are related, although the exact commentary on these issues requires extensive comparative studies and reappraisal of scholarly and historical texts from this interdisciplinary perspective. 
1) Coalition of physicians and architects'/ artists' guilds: Concerning this topic, there are at least three theoretical consequences that can be surveyed. Firstly, medical texts deal with the theoretical foundations of the human relationship within built and natural environments. The practical application of these foundations in art and architecture indicates an informal coalition between physicians and architects' or artists' guilds, especially in the early centuries. Secondly, according to the previous hypothesis, architects and artists do not seem to have relied solely on the acquisition of experience and tacit knowledge in the creation of their works and did not need the teachings of physicians. Thirdly, the interdisciplinary relationships of architecture and art with the natural sciences and medicine cannot be limited to the Muslim society. The historical evolution of the theoretical bases in this interdisciplinary field is the second issue to be reassessed.

2) The evolution of the interdisciplinary relationship of medicine and architecture: After the transmission of medical sciences to the Muslim society and their development (from the $8^{\text {th }}$ to the $11^{\text {th }}$ century), the theoretical foundations of this interdisciplinary field evolved, and its instructions were applied in architecture and decorative arts. Hence, to understand the evolution of the theoretical foundations of this field, apart from studying the progress and continuation of the ancient scientific heritage in the medical sources of the Muslim society, we should consider the return and translation of this evolved heritage to Europe in the $11^{\text {th }}$ and $12^{\text {th }}$ centuries. This hypothesis requires a comprehensive comparison between these texts and European medical sources.

It is expected that the assumptions and considerations of this paper can provide new grounds for research to be performed by scholars of this interdisciplinary history and can inspire the design field to address healthy places and environmental health knowledge.

\section{Bibliography}

Abū Sahl al-Masihi 2000: Kitab-al-Mi'a fil- Tibb [Book of the Hundred (on medicine)]. Sanagustin, F. ed. Damascus: French Institute of Arab Studies.

Abū Zayd Balkhī 2005: Masāilị̧ al-Abdān wa-al-Anfus [Sustenance for body and soul]. Mișrī. M \& Khayyāt, M. H. ed. Cairo: Ma‘had al-Makhṭūṭāt al-'Arabīyah.

Adams, Francis 1886: The Genuine Works of Hippocrates. Vol.1. London: Sydenham Society. 
Al-Akhawain̄i al-Bukhārī 1965: Hidāyat al-Muta'allimin fì al-Tibb [The students' handbook of medicine]. Matini, J. ed. Mashhad: Mashhad Univ. Press.

Al-Dimašqī 2009: Risālah al-Hārūniyya [Hārūniyya treatise]. Vol.1. Tehran: Iran University of Medical Sciences Press.

Al-Fārābi 2003: Fosule Montaz̧a'a [Civil Affair]. Traslated into Persian by Malekshahi, H. Tehran: Soroush Publishing.

Al-Ghazūlī 1881: Kitāb Matăli al-Budūr wa-Manāzil al-Surūr [The Golden Treatise]. Cairo: Maṭba'at Idārat al-Watan.

Al-Hamawī 1987: Nür al-'Uyūn wa-Jämi' al-Funūn [Light of the Eyes and Compendium of Arts]. Qala'a Ğ̄in, M.A and Al- Wafā’̄̄, M.Z. ed. Riyāḍ: King Faisal Center for Research and Islamic Studies.

Al-Harrānī 1928: Kitāb al-Dhakhira fì 'Ilm al-tibb [Treasure of medical science]. Subhī. J., ed. Cairo: Government Press.

Al̄̄ ibn Mūsā ar-Riḍā 1982: Al-Dhahabiah [The Golden Treatise]. Najaf, M.M. ed. Qom: al-Maṭba 'a al-Khayyām.

Al-Marräkushī 1881: Kitab Al-Mojab fee Talkhis Akhbar al-Maghreb [The book of wonder, on the summary of news of the Maghreb]. $2 \mathrm{~d}$ ed, rev. and corr. by Reinhart P. A. Dozy. Leyden: E. J. Brill.

Al-Rāzī 2000: Al-Hawi fì al-Tibb [The comprehensive book on medicine]. 8 Vols. Ismāil, M.M. ed. Beirut: Dar al- Kotob al- Ilmiyah.

Al-Rāzī 2005: Ketab al-Morshid av al-Fosool [The Guide (on medicine)]. Traslated into Persian by Zaker, M.E, Research: Alborzkey Eskandar. Tehran: Publication of Tehran University of Medical Sciences.

Al-Rāzī 1987: Al-Manșūri fi al-Tibb [The Book on Medicine for Mansur]. Al-Bakry alSiddiky, H. ed. Kuwait: Publications of Institute of Arab Manuscripts.

Al-Ruhāwi 2008: Adab al-Tabib [The physician's guide]. Samerraei, K \& Salman, D. ed. Tehran: Iran University of Medical Sciences Press.

Al-Tabarī 1928: Firdaws al-Hikema fi l-Tibb [The Paradise of Wisdom in Medicine]. Siddiqi, M. Z. ed. Birlīn: Aftab Press.

Al-Teflisi 2011a: Bayān al-Tibb [Explanation of Medicine]. Razavi Borqei. S.H. ed. Tehran: Nashre Ney.

Al-Teflisi 2011b: Kefāyat al-Tibb [Sufficiency in medicine]. ParsaPour. Z. ed. Tehran: Institute for Humanities and Cultural Studies.

Al-Zahrāwī (Abulcasis) 2004: Al-Tașrif li-Man 'Ajïa 'an al-Ta'lif [qui componere haud. Hammāmi, S.M., ed. Kuwait: Foundation for the Advancement of Sciences. 
Jafar Taheri

The impacts of architecture and decorative arts on health...

Averroes 2005: Al-Kulliyät fi al-Tibb [Generalities]. Al-Mazidi, A.F, ed. Beirut: Dar al- Kotob al- ilmiyah.

Avicenna 1999: Al-Qānūn fì al-Tibb [The Canon of medicine]. 3 Vols. Zannāvi, M.A. ed. Beirut: Dar al- Kotob al- ilmiyah.

Avicenna 2008: Hefz al-Sehba [Maintaining health]. Translated into Persian by Qazwini, A. Tehran: Iran University of Medical Sciences Press.

Bannā, Habibullāh 2014: Risālah Gelkārī: Fotowatnāme Bannāyān [Epistle on Masonry]. Tehran: Iranian Academy of the Arts.

Barrucand, Marianne; Bednorz, Achim 1992: Moorish Architecture in Andalusia. Köln: Taschen. ISBN 10: 3822896322ISBN 13: 9783822896327

Behrens-Abouseif, D. 1989: Islamic Architecture in Cairo: An Introduction. Leiden: E. J. Brill. ISBN 10: 9774242033 ISBN 13: 9789774242038

Bianca, Stefano 2000: Urban Form in the Arab World: Past and Present. London: Thames \& Hudson. ISBN 10: 3728119725ISBN 13: 9783728119728

Currie, J. M. 2007: The Fourth Factor: A Historical Perspective on Architecture and Medicine. Washington, D.C.: AIA, Academy of Architecture for Health. ISBN 10: 1571650180ISBN 13: 9781571650184

Dols, Michael W. 1987: The Origins of the Islamic Hospital: Myth and Reality. [In:] Bulletin of the History of Medicine 61(3), pp. 367-390.

Elsheshtawy, Y. 2008: The evolving Arab city: Tradition, modernity and urban development. London: Routledge. ISBN 10: 0415665728ISBN 13: 9780415665728.

Elgood, Cyril 1951: A Medical History of Persia and the Eastern Caliphate: from the Earliest Times until the Year A.D. (1932). Cambridge: Cambridge University Press.

Ettinghausen, Richard; Grabar, Oleg 1994: The Art and Architecture of Islam: 6501250. New Haven, CT: Yale Univ. Press. ISBN 10: 0300053304ISBN 13: 9780300053302

Galen 1977: Kitāb Jälīnūs fì Firaq al-Tibb lil-Muta'alliminn [Galen's book on Branches of medicine for students]. in the trans. of Hunayn ibn Ishạā. Sālim, M. S. ed. Cairo: Al-Mațba a Dar al-Kutub.

Galen 1982: Kitāb Jālīnūs ilá Ghalawqun fì al-Ta'attì li-Shifä' al-Aamrad: Maqālatān [Galen's Book to Ghalawqun to Heal Diseases: Essays]. in the trans. of Hunayn ibn Ishạāq. Sālim, M. S. ed. Cairo: Al-Hay’ah al-Mișrīyah al-'Āmmah lil-Kitāb.

Gerlach-Spriggs, Nancy et al. 1998: Restorative Gardens: The Healing Landscape. New Haven: Yale Univ. Press. ISBN 10: 0300072384ISBN 13: 9780300072389.

Gesler, W. M. 1992: Therapeutic landscapes: Medical issues in light of the new cultural geography. Social Science \& Medicine, 34(7), 735-746. doi: 10.1016/ 0277-9536(92)90360-3 


\section{Varia}

Rashīd al-dīn F. Hamadānī 1945: Mukeatabāt-i Rashìdì [Letters of rashid al-din fadl allab]. Shafí, M., ed. Lahore: Panjāb University Oriental Publications.

Hristakieva, Evgenyia 2005: 'Climatotherapy in Dermatology: Why, How and When'. Trakia J Sci, 3(4): 27-31.

Ibn Abī Ușaybi'‘a 1956: Uyun al Anba' fi Tabaqāt al-Atibba’ Biographies of selected physicians]. 3 Vols. Beirut: Dar al- Fekr.

Ibn al-Jawzi 2010: Laqt al-Manafi' fi al-Tibb [Collection of Medicine Benefits]. Marzūq. Cairo: Mațba‘at Dār al-Kutub wa-al-Wathā’iq al-Qawmīyah bi-al-Qāhirah.

Ibn Butlān Baghdādī 1987: Tarjumah-'i Takwìm al-Sihbat [Translation of Health assessment]. By an unknown translator. Yusufi, G.H. ed. Tehran: Scientific and Cultural Publications Company.

Ibn Hubal 1943: Kitāb al-Mukhtārāt fi al-Tibb [The Book of Selections in Medicine]. Vol. Hyderābād Deccan: Jami'ah Usmāniyah Encyclopedia.

Ibn Imrān 2015: Medical Treatises. Muqaddas, E. ed. Tehran: Nilobarg.

Ikhwān al-Ṣafā’ 2005: Rasāill [Epistles]. 4 Vols., Vol. 2. Beirut: Alaalami Library.

İsá Bak, Ahmad 1981: Tārikh-i al-Bimāristānāt fil Islām [History of hospitals in Islam]. Beirut: Dar al-Raed al-Arabi Press.

Jorjāni, Zain-al-din E. 2005: Ketāb al-Ā̄rāra al-Tebbiya wa al-Mabāhẹt al-'Alä iya [Medical purposes and Aläei's topics]. 2 Vols. Tajbakhsh, H. ed. Tehran: University of Tehran \& Academy of Sciences of Iran Press.

Jorjāni, Zain-al-din E. 1990: Khofi Aläei [Alaei's footwear (on medicine)]. Najm Abadi, M., \& Velayati, A. A., ed. Tehran: Ettelaat Publications.

Jorjāni, Zain-al-din E. 2014: Zakhireh Khärazmshāhī [Treasure of Kharazmshahi]. 3 Vols. Alinaghi, H \& Nezhad Fallah, H., ed. Tehran: Safir-e Ardehal Press.

Karīm Ibn Ibrāhim 2008: Risālah Dalläkiah [Epistle on medicine in bathroom]. Tehran: Iran University of Medical Sciences Press.

Kheirabadi, Masoud 2000: Iranian Cities: Formation and Development. Texas: Texas Univ. Press. ISBN 10: 0292743165ISBN 13: 9780292743168

Land, K. V.; Baker, P. A.; Nijdam, H. 2012: Medicine and space: Body, surroundings, and borders in antiquity and the Middle Ages. Leiden: Brill.

Lawson, B. 2010: Healing architecture. Arts \& Health 2(2), pp. 95-108. DOI: 10.1080/17533010903488517.

Lindberg, David C. 2008: The Beginnings of Western Science: The European Scientific Tradition in Philosophical, Religious, and Institutional Context, Prehistory to A.D. 1450. Cambridge: International Society for Science and Religion. ISBN 10: 0226482057ISBN 13: 9780226482057. 
Maciocia, Giovanni 2015: The Foundations of Chinese Medicine: A Comprehensive Text for Acupuncturists and Herbalists. 3rd Edition. Edinburgh: Elsevier. ISBN 10: 0443039801ISBN 13: 9780443039805.

Majūsī Ahwāzī 2009: Kämil al-sina'ah al-tibbīyyāh [The complete book of the medical art]. 3 Vols., Translated into Persian by Khālid Ghaffārī, S.M. Tehran: McGill University and Institute of Islamic Studies Publications.

Malek-al-Ațebbā 2009: Hefž al-Sehha-ye Nāseri [Naseri's Maintaining Health]. Choopan R, ed. Tehran: Al- Ma‘ī Publication.

Marcus, Clare Cooper et al. 2014: Therapeutic Landscapes: An Evidence-Based Approach to Designing Healing Gardens and Restorative Outdoor Spaces. Hoboken, NJ: Wiley. ISBN 10: 1118231910ISBN 13: 9781118231913.

Miller, Timothy S. 1997: The Birth of the Hospital in the Byzantine Empire. Baltimore: The Johns Hopkins Univ. Press. ISBN 10: 0801856574; ISBN 13: 9780801856570.

Nasr, Seyyed Hossein 2007: Religion \& the Order of Nature. Cambridge: International Society for Science and Religion.

Papadopoulo, Alexandre 1989: Islamic Architecture [Mi'mārīi Islāmī]. Traslated into Persian by Jazanī, H. Tehran: Markaz-i nashr-i farhangi-i Raj’-

Pormann, Peter E. and Emilie Savage-Smith 2007: Medieval Islamic Medicine. Edinburgh: Edinburgh Univ. Press. ISBN 10: 0748620672 / ISBN 13: 9780748620678

Porter, D 1999: Health, Civilization, and the State: A History of Public Health from Ancient to Modern Times. London: Routledge. ISBN 10: 0415200369; ISBN 13: 9780415200363.

Ragab, Ahmed. 2018: The medieval Islamic hospital: Medicine, religion, and charity. Cambridge: Cambridge University Press. ISBN: 9781107524033.

Raymond, Andre 1985: The Great Arab Cities in the 16th-18th Centuries: An Introduction. New York: New York Univ. Press. ISBN 10: 0814773915ISBN 13: 9780814773918

Sánchez, Expiración García 1992: Agriculture in Muslim Spain. [In:] Jayyusi, Salma Kadra (ed.), Chief consultant to the editor Manuela Marín, The legacy of Muslim Spain. Leiden, pp: 987-999.

Siraisi, Nancy G. 1990: Medieval and Early Renaissance Medicine: An Introduction to Knowledge and Practice. Chicago: Chicago Univ. Press. ISBN 10: 0226761304; ISBN 13: 9780226761305.

Tabbaa, Yasser 2003: The functional aspects of medieval Islamic hospitals. [n:] M. Bonner, M. Ener, A. Singer, Poverty and charity in Middle Eastern contexts. 
Albany: State University of New York Press, pp. 95-119. ISBN 10: 0791457389; ISBN 13: 9780791457382.

Taheri, Jafar 2016: Bathroom in Medieval Islamic Medical Texts: Theory and Practice. Journal of Researches in Islamic Architecture 4 (1), pp. 46-61.

Taheri, Jafar 2014: The Climatic Plans of Sustainable Environment in Islamic Medicine. Journal for the History of Science, 12(1), pp. 17-37.

Ullmann, Manfred 1978: Islamic Medicine. Edinburgh: Edinburgh Univ. Press. ISBN 10: 0852243251; ISBN 13: 9780852243251.

Ulrich, Roger S. 1995: Biophilia, Biophobia and Natural Landscapes. [In:] Stephen R. Kellert, Edward O. Wilson (ed.). The Biophilia Hypothesis. Washington, D.C. Island Press; Reissue edition, pp. 73-137. ISBN 10: 1559631473; ISBN 13: 9781559631471.

Vitruvius Pollio 1914: Vitruvius: Ten Books on Architecture. Morgan, M. H. ed. Cambridge: Harvard University Press. 